\title{
ESTUDO DE MISTURAS DE SOLO E AGREGADO PARA USO COMO CAMADA DE BASE EM VIAS MUNICIPAIS DA PLANÍCIE COSTEIRA SUL DO RIO GRANDE DO SUL
}

\author{
RÉGIS PINHEIRO MARIA | UFSM \\ CEZAR AUGUSTO BURKERT BASTOS, Dr.|FURG
}

Analisando a malha urbana nos municípios da região sul do estado do Rio Grande do Sul, é possível observar a crescente demanda por vias pavimentadas, seja em bairros periféricos ou vias com considerável fluxo de veículos. Essa situação decorre da falta de investimentos em pavimentação das vias já existentes, aliado à crescente expansão da infraestrutura em função do desenvolvimento da região.

Outro fato a se destacar é o alto custo dessas obras de pavimentação, uma vez que o solo local não apresenta resistência mecânica suficiente para sua aplicação direta em camadas de base ou sub-base de pavimento. Em função disso, faz-se necessário o emprego de materiais de empréstimo considerados mais nobres (p.ex. brita graduada), com elevado custo de aquisição e transporte, conforme a localização da obra.

Dentro deste panorama, este estudo avaliou materiais de empréstimo comumente comercializados na região, denominados: saibro fino (SF) e saibro britado (SB), saibro fino misturado a material pétreo britado, oriundos de jazidas localizadas no interior do município do Capão do Leão/RS. Foram propostas e avaliadas quatro misturas de solo e agregado, definidas segundo métodos de estabilização granulométrica. As três primeiras misturas foram orientadas pelo método empírico, onde foram acrescentados percentuais crescentes (25\%) de material pétreo britado ao saibro fino. A mistura 4 foi estabelecida com base no método estatístico e de Rochfuchs, utilizando a curva de Talbot (60\%SB+40\%SF).

Foram realizados ensaios nos materiais constituintes bem como nas misturas, dentre os ensaios pode-se destacar os utilizados para classificação geotécnica pela ABNT, HRB e SUCS, ensaios de classificação pela metodologia MCT e G-MCT e caracterização do material britado a partir de ensaios usuais para agregados.

Também foram verificadas as propriedades de compactação e de resistência utilizando ensaios de compactação Proctor, nas energias do Proctor Normal, Intermediário e Modificado, bem como a determinação do Índice de Suporte Califórnia (ISC), apresentado na figura 1 , e seu respectivo potencial de expansibilidade.

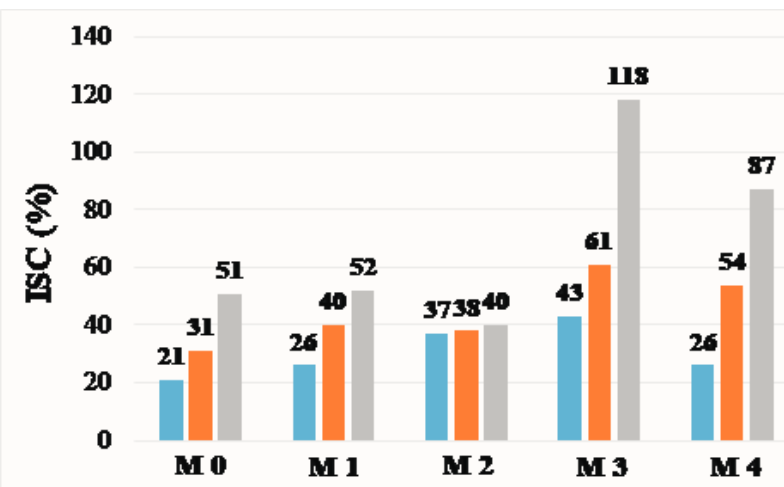

Figura 01 - Índice de Suporte Califórnia no teor de umidade ótimo Fonte: Autor.

Após análise das propriedades físicas e desempenho mecânico das misturas obteve-se melhor desempenho, conjugado ao menor teor de material britado, para a mistura 4, com ISC igual a 54\% (na energia do Proctor Intermediário). Cabe salientar que os editais de licitação para aquisição de materiais constituintes de camadas de pavimento de vias nos municípios da região exigem materiais com ISC $\geq 50 \%$, com isso, apenas as misturas M3 e M4 atendem, priorizando-se a M3 por apresentar um menor percentual de agregado, reduzindo custo.

É importante destacar, também, que a utilização de rocha granítica alterada nas misturas com o material fino, além de aumentar o desempenho mecânico do material, possibilita uma destinação para o material que por estar em alteração intempérica não possibilita seu emprego como agregado são (pedra britada para construção civil).

Outro fato importante é que a técnica permite maior e melhor aproveitamento de áreas já licenciadas ambientalmente, com planos de reabilitação dos terrenos já em andamento. $\mathrm{O}$ que reduz a necessidade de exploração de outras áreas intactas na região. 
